\title{
Treatment of female and male inpatient crack users: a qualitative study
}

\author{
Tratamento de mulheres e homens usuários de crack internados: \\ um estudo qualitativo
}

\author{
Rosemeri Siqueira Pedroso, Félix Kessler, Flavio Pechansky*
}

\begin{abstract}
Objective: To map treatment trajectories in a sample of male and female crack users through their narratives about the course of treatment seeking and their attempts to access health care services in Brazil.

Methods: Qualitative study of a purposive sample (five female and nine male hospitalized crack users) using semi-structured interviews. The interviews were transcribed and data explored using content analysis.

Results: Respondents reported difficulties getting access to hospitalization, relapse after discharge, and abandonment of treatment. There seems to be a peculiar model of behavior for women and men while dealing with craving for crack: while women got involved with prostitution and consequently became infected with HIV, every men of the sample reported criminal involvement.

Conclusions: The relationship between relapse and a social environment conducive to consumption, associated with belief or disbelief in spiritual support, prostitution, and the legal complications arising from the use of crack, are relevant issues and should be taken into consideration in the development of preventive actions aimed at this specific population.
\end{abstract}

Keywords: Treatment, crack, drug users, treatment services, treatment access, qualitative study.

\section{Resumo}

Objetivo: Mapear as trajetórias de tratamento em uma amostra de homens e mulheres usuários de crack, através de suas narrativas acerca do percurso de busca por tratamento e suas tentativas de ter acesso ao sistema de saúde brasileiro.

Método: Estudo qualitativo de uma amostra intencional (cinco mulheres e nove homens usuários de crack internados) utilizando entrevistas semiestruturadas. As entrevistas foram transcritas e os dados explorados utilizando-se a técnica de análise de conteúdo.

Resultados: Os entrevistados referiram dificuldades em obter acesso à internação, recaídas após a alta e abandono do tratamento. Parece existir um modelo de comportamento peculiar às mulheres e aos homens para lidar com a fissura pelo crack: enquanto as mulheres se prostituíram e, consequentemente, infectaram-se pelo HIV, todos os homens da amostra referiram envolvimento com o crime.

Conclusões: As relações entre recaída e um ambiente social propício ao consumo, associadas a crença ou descrença em um auxílio espiritual, prostituição e às complicações legais decorrentes do uso de crack, são pontos relevantes e devem ser levados em consideração no desenvolvimento de ações preventivas voltadas a essa população específica.

Descritores: Tratamento, crack, usuários de drogas, serviços de tratamento, acesso ao tratamento, estudo qualitativo.

\footnotetext{
*Center for Drug and Alcohol Research, Hospital de Clínicas de Porto Alegre, Universidade Federal do Rio Grande do Sul (UFRGS), Porto Alegre, RS, Brazil. Financial support: National Secretariat for Drug and Alcohol Policies (SENAD).

Submitted Dec 14 2011, accepted for publication Feb 23 2012. No conflicts of interest declared concerning the publication of this article.

Suggested citation: Pedroso RS, Kessler F, Pechansky F. Treatment of female and male inpatient crack users: a qualitative study. Trends Psychiatry Psychother. $2013 ; 35(1): 36-45$.
} 


\section{Background}

Treatment seeking trajectories among users of crack, combined or not with other psychoactive substances, can be inferred as we look at the great numbers of patients seeking help at detoxification units of overcrowded hospitals in Brazil. Notwithstanding, very few Brazilian studies have focused on evaluating the treatment provided for crack users; the only paper currently available describes samples consisting predominantly of men aged between 20 and 30 years and not including female crack users. ${ }^{1}$

We believe in a dynamic profile of crack users: nearly every day, patients bring in new forms of consumption, which spread among users regardless of gender, age or social class. Thus, we also deem it important to give voice to female crack users, expanding the characterization of crack users and valuing the increasingly diverse clientele who seeks treatment and is part of a broader group at risk for sexually transmitted diseases, including AIDS. ${ }^{2-6}$

The trajectory of these patients - successful or unsuccessful - in the search for health care is currently unknown. Evaluating different trajectories of drug use and treatment seeking among crack users would help characterize our health care system and reveal its fragility when faced with the large demand imposed by crack users. In particular, such an analysis would expose the patients' vulnerability to relapse and other factors pertaining to the maintenance of abstinence, which have been significantly associated with a longer period of aftercare after hospital discharge. ${ }^{5}$ On the one hand, there is reason to believe that several characteristics influence abstinence rates among crack users. Siegal et al., ${ }^{3}$ for example, followed 229 crack users during 18 months and found that, after 6 months, 45.4\% had relapsed. Based on the subjects' trajectories of abstinence or relapse, three groups were identified: abstinence in the course of use, consistent use during the period, cycling between abstinence and use during the period. On the other hand, reports obtained during interviews with crack users about their course of treatment could potentially improve our knowledge about the care that should be delivered to this specific and differentiated clientele, especially with regard to treatment approaches, the involvement of experts in drug dependence, and also the involvement of the entire framework of public policies that dictate the model of care, often deficient and outdated..$^{2,4}$

Taking into consideration that the use of crack has been observed in both genders and in different social classes and age groups, ${ }^{4-6}$ the purpose of this study was to map treatment trajectories of male and female crack users receiving inpatient treatment at a psychiatric hospital in Porto Alegre, the southernmost state capital of Brazil (current population: 1.5 million inhabitants). A second aim of the study was to assess other, still scarcely studied, aspects related to the treatment of crack users, such as initiation of the use of licit and illicit drugs in general and crack in particular, use of licit and illicit drugs by family members, treatment attempts, previous hospitalizations, relapse, spiritual help seeking, legal problems, prostitution, and HIV infection.

\section{Methods}

\section{Design}

We used a qualitative research methodology, with the viewpoint of crack users as reference. This methodological approach aimed at understanding the trajectory of each subject from their first use of crack and other drugs over their lives, treatment and relapse, and hospital to which the user was admitted at the time of the interview. ${ }^{7-10}$

\section{Sample}

Samples were collected between December 2009 and January 2010 at a Brazilian psychiatric hospital that serves patients living on the outskirts of Porto Alegre. The hospital has a male detoxification unit dedicated exclusively to treating crack users, although some of the patients treated there had also used other psychoactive substances throughout life. All the 11 men who were at the detoxification unit concluded the interviews. Another unit, aimed at female psychotic patients, had no specific treatment program for crack users. Nevertheless, at the time of data collection, six female crack users were receiving treatment there; all of them started the interview process, but only five completed it (one dropout).

Interviews were conducted until theoretical saturation, as recommended by several authors. ${ }^{7,9,10}$ The process of analysis used to determine theoretical saturation is described elsewhere. ${ }^{11}$ Briefly, it includes full interview audio transcription, careful reading of each interview, definition of categories according to previously established topics, grouping of data analyzed in each interview (already coded according to topics), and final verification of categories for content analysis. In this study, sampling closure by theoretical saturation occurred on the 14th interview, but the 15th and 16th interviews were carried out to confirm narrative repetitions (two male inpatients; data not included in the analysis). The principal investigator continuously evaluated theoretical saturation of the sample collected, as well as the process of analysis since the beginning of data collection. 


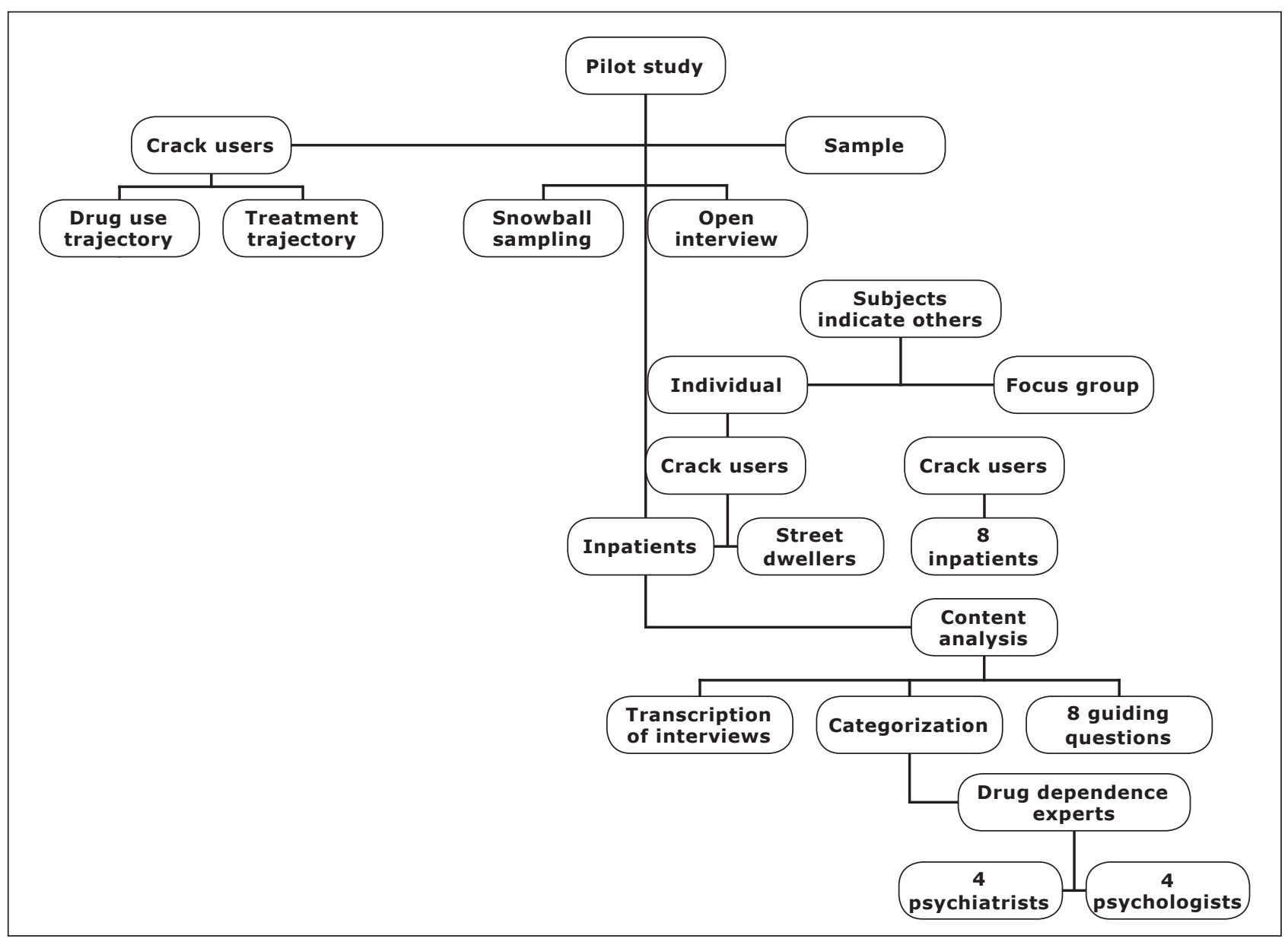

Figure 1 - Pilot study flow chart

\section{Pilot study}

In order to better prepare for the final process of data collection, the principal investigator collected qualitative data on the treatment trajectory of crack users in a pilot study (Figure 1). Crack users and street dwellers selected at different neighborhoods of Porto Alegre, who were not related and did not know each other, were interviewed. The snowball (chain) sampling technique was used, ${ }^{12}$ i.e., the first respondents indicated others to be interviewed, and so forth. Five chains were used, to ensure a heterogeneous sample. Another part of the sample comprised inpatient crack users.

Eight crack users admitted to the detoxification unit were interviewed in a focus group. An expert panel comprising eight drug dependence specialists (four psychiatrists and four clinical psychologists) analyzed the transcribed interviews of the eight inpatient crack users who participated in the focus group. ${ }^{13}$ Our original plan was to use a structured interview, with closed questions, in the focus group, in order to work with previously defined answer categories and ensure a greater uniformity of data. However, as a result of the pilot study, we decided to use a brief questionnaire to collect sociodemographic data and a semi-structured interview with standard questions and predetermined answers to assess the users' report about their history of use and treatment seeking (Table 1 ). The eight guiding questions comprising the focus group interview were selected based on literature review and also on the experience of the principal investigator in the care of addicted patients. ${ }^{14}$

\section{Procedures}

Interviews were conducted on the 7th day of hospitalization and abstinence. After obtaining the participants' consent, the audio of the interviews was recorded for subsequent transcription, as explained in the informed consent form. The study was approved by the Research Ethics Committee (institutional review board-equivalent) of Hospital de Clínicas de Porto Alegre. 
Table 1 - Guiding questions in the semi-structured interview

\section{Questions}

1. What was your life trajectory like before you first used crack?

2. At what age did you start using drugs before crack?

3. How many times were you hospitalized before?

4. How many times did you try to be hospitalized?

5. In your opinion, which factors have contributed to your relapse after discharge or to abandonment of previous hospitalizations?

6. Have you ever been involved with crime, prostitution or under arrest due to your crack addiction?

7. Has your physical health been affected due to the use of crack?

8. Do you believe that faith, religion and/or spirituality may help you to abandon crack?

\section{Objectives}

Aspects related to birth, schooling, work, family, and friendships. Age at the beginning of use of licit and illicit drugs.

Trajectory of previous hospitalizations.

Hospitalization seeking trajectory: number of attempts.

Risk factors related to crack use.

Legal aspects: crime or exchange of sex for crack.

Physical aspects: clinical conditions.

Spiritual beliefs related to abstinence from crack use.

\section{Transcript of interviews}

In order to preserve the identity of study participants, each interview was coded with a number. The transcription of audio files was conducted by the principal investigator. ${ }^{14}$

\section{Focus group: expert panel}

In two meetings lasting for 1 and a half hour each, the same panel of experts of the pilot study (i.e., four psychiatrists and four psychologists) read the sample reports and selected treatment seeking indicators for crack users. ${ }^{13}$

\section{Results}

\section{Sample characteristics}

We interviewed five female and nine male crack users, with a mean age of 25.6 years (range: 20 to 30 years). Mean years of education were 8.4 for the whole sample, and the mean household monthly income was US\$ 721. Regarding marital status, four participants were married $(28.57 \%)$, and the remainder were single. Sample characteristics are shown in Table 2.

\section{Crack use and treatment seeking trajectories}

Based on the questions shown in Table 1 and on interview results, the panel of experts established the following 14 topic categories for data analysis: 1 ) beginning of licit drug use; 2) beginning of illicit drug use; 3 ) beginning of crack use; 4) use of illicit drugs among relatives; 5) age at the beginning of use of other drugs and crack; 6) treatment attempts and previous hospitalizations; 7) motivation for treatment; 8) legal problems arising from the use of crack; 9) prostitution; 10) HIV infection; 11) search for spiritual help; 12)
Table 2 - Sample characteristics

\begin{tabular}{ccc}
\hline $\begin{array}{c}\text { Name initial, } \\
\text { age and gender }\end{array}$ & $\begin{array}{c}\text { Education } \\
\text { (years) }\end{array}$ & $\begin{array}{c}\text { Mean household } \\
\text { monthly income (US\$) }\end{array}$ \\
\hline S22F & 3 & 1,188 \\
M27F & 11 & 891 \\
R26F & 8 & 891 \\
E28F & 8 & 297 \\
A29F & 8 & 416 \\
P20M & 9 & 356 \\
T22M & 10 & 713 \\
J22M & 10 & 594 \\
N25M & 8 & 416 \\
L25M & 8 & 1,188 \\
B27M & 4 & 297 \\
D27M & 8 & 356 \\
I29M & 8 & 416 \\
F30M & 14 & 2,078 \\
\hline F = female; M male. & &
\end{tabular}

hospitalization and family/affective losses; 13) relapse and a social environment conducive to the consumption of crack; and 14) relapse after discharge or abandonment of previous hospitalizations.

For the purposes of this study, the principal investigator grouped the main results into five domains, described and commented on below, with emphasis on the patients' stories about treatment seeking, hospitalization, and relapse after discharge. Keywords representative of all categories mentioned above were selected for discussion.

Domain 1: Beginning of drug use (licit and illicit drugs and crack)

Respondents believed that the use of tobacco and alcohol by family members facilitated their access to and experimentation of licit drugs and was responsible for their early start of drug consumption.

My grandmother used to smoke and I collected all cigarette butts and smoked hidden from her. I was twelve. (R26F) 
I smoke cigarettes since I was 6 or 7 years old... I lighted the cigarette for my mother and I used to light the cigarette for my mother and [then] take a few puffs myself... (J22M)

My dad used to drink... it is a shame... I started drinking alcohol at 8... but not directly, like this, right... just trying a little bit, see? (B27M)

Everybody smokes and drinks back home. Two of my older brothers use cocaine and crack. (I29M)

Regarding the use of illegal drugs, marijuana appears first, coming shortly before cocaine.

I started to use marijuana at 12 years... everybody used it... after that came the dust [cocaine]. (S22F) Marijuana appeared naturally. Crack is the major problem. Today I don't even consider it a drug. If I had stuck to marijuana I wouldn't be here. The worst problem is crack. At 12 I smoked marijuana and was happy. I only used cocaine some time later. (J22M) If you ask, everybody will say the first step was the harmless marijuana. Who has never smoked a joint? After that the normal path was to use cocaine. Crack is more recent, right? (E28F)

The first use of crack seems to be related to the influence of friends and curiosity about the drug.

I searched for the stone [crack rock] for my brotherin-law and I did not even know what it was. One day there... I smoked with him and some friends. It was curiosity. (S22F)

I only used crack at 26 and it was because of friendship... I guess. (M27F)

My stupidity was to believe that crack was something innocent. My friends talked me into it. (E28F)

We get blinded and let others influence us. I used crack for curiosity. (A29F)
[...] I was quiet at home; there came a mate... a friend of mine. Look what I got here... a stone... So I took it, tried it, and fell in love, right? (B27M)

Respondents believed that the use of illicit drugs by their family reinforced their own use, but saw their crack addiction as their own responsibility, as a personal vulnerability to the drug.

My foster father uses marijuana... and my older biological brother uses cocaine. But they always told me not to use. (T22M)

I have two brothers who use crack and were never treated. Funny thing is they have helped my mother to forcibly hospitalize me. (I29M)

Regarding age at initiation of the use of crack and other drugs, it is clear that the respondents' indirect contact with other drugs, by observing the use of other psychoactive substances by family members and friends, has influenced and encouraged the beginning of their own trajectory of crack use.

Table 3 shows the respondents' ages at the beginning of use of licit and illicit drugs and their evolution to the use of crack.

\section{Domain 2: Treatment seeking trajectory, previous hospitalizations, and relapse}

This section brings examples that illustrate the clinical need for treatment, with subjects reporting from one to five treatment attempts.

I called my aunt and said we were trying a court order for me to be hospitalized. (F30M)

After three attempts, my mother could get a court order to hospitalize me. The Brigade (Military Police) picked me up at home. (S22F)

[...] the guys told me I had to attend CAPS

Table 3 - Reported age of drug initiation

\begin{tabular}{|c|c|c|c|c|c|}
\hline Name initial, age and gender & Alcohol & Tobacco & Marijuana & Cocaine & Crack \\
\hline $\mathrm{S} 22 \mathrm{~F}$ & 12 & 12 & 12 & NU & 12 \\
\hline M27F & 16 & 26 & 27 & 27 & 26 \\
\hline $\mathrm{R} 26 \mathrm{~F}$ & 16 & 12 & 14 & 15 & 23 \\
\hline E28F & 15 & 12 & 15 & 16 & 20 \\
\hline A29F & 14 & 15 & 16 & 17 & 21 \\
\hline P20M & 15 & 16 & 16 & NU & 16 \\
\hline T22M & 12 & 12 & 14 & 17 & 18 \\
\hline N25M & 12 & 12 & 13 & 21 & 21 \\
\hline L25M & 13 & 20 & 16 & 16 & 23 \\
\hline B27M & 08 & 12 & 13 & 18 & 18 \\
\hline D27M & 12 & 12 & 17 & 20 & 27 \\
\hline I29M & 12 & 12 & 18 & 20 & 26 \\
\hline F30M & 14 & NU & 14 & 14 & 24 \\
\hline
\end{tabular}

$\mathrm{F}=$ female $\mathrm{M}=$ male $; \mathrm{NU}=$ never used 
(Psychosocial Care Center, where crack users receive care that is equivalent to that received at day hospitals) for them to evaluate my case and see if hospitalization was needed, and I was saying that I was dying and needed to be locked. Then I came here (hospital) about five times and nothing... until one day I was crazy at night... I wanted to be admitted to the hospital, so I went to a policeman who told me, oh! Try a court order. (F30M)

CAPS works... but does not hold the guy... if the guy is craving the drug, he can leave, so being an inpatient here [hospital] is better. But there... the guy stays 1, 2 , or 3 days, and then they send them to a hospital. There are other illnesses there, not just drug use. I waited for 3 days to be admitted here. (J22M)

The politicians go on TV and say one thing... But when we need it is not so. This is the first time I am hospitalized. I went to Postão [local health care unit] at my neighborhood and they sent me home. And there I was... begging to be hospitalized... I could no longer stay on the street using crack. I had no family anymore. I went back to Postão and stayed there... until I was assisted. I stayed there for 3 days taking medicines and they sent me here. (D27M)

The decision and motivation to be hospitalized comes from the crack users' concern regarding emotional and family loss.

I made many people suffer. My father is well known in the city I live and he is ashamed of me. That's why I am back here. I wanted to be someone else. I didn't want to be like this. (R26F)

[...] there was a small couch where my father's dog used to sleep. I pushed him off the couch, and he was growling at me. And I said: you sleep here everyday; today is my day... and I lay down at that place. I stayed there until early morning, and when my mother woke up, she couldn't believe I was there, because I was craving the drug, but I didn't leave, and I said I wanted to smoke, but I was not going after it. I want help! Send me to a hospital. (N25M)

With regard to relapse after discharge from hospital, reports reveal concerns with the place of residence, proximity to traffic, and old friendships that hinder the maintenance of abstinence from crack.

I was hospitalized 13 times, around twice a year. I can remain clean for a period... the maximum was 1 year and 2 months. It seems there is a period of validity, so I am clean for some time and the relapses may start again, right? (F30M)
I live with crack next door. That disturbs me and that's what made me fall in again. (E28F)

The environment influenced. My biological mother lives here in the slum close to the prison and sometimes I would visit her and had to go through alleys and stuff, right? And in the midst of these alleys, people were getting high. (T22M)

To illustrate the common discourse referring to relapse after previous hospitalizations, we provide accounts of users who were discharged and users who abandoned treatment.

I've been hospitalized twice. My last stay lasted 33 days, I was discharged and returned to use after 3 days. (R26F)

I ran away from the hospital after a week. I couldn't stand it... and went back to crack the following day. (E28F)

I was in the hospital for 10 days, and then I ran away and returned to drug use. I was arrested selling drugs and stayed in prison for 5 months. I went out on parole and the first thing I did was to go back to the drug den again. (N25M)

My case is pretty serious... I was hospitalized 13 times. Last time I stayed here for 35 days. I was discharged and remained clean for only 7 months. It's always like this... I am well and I relax... then, when I see it, I'm using again. (F30M)

Only two patients were hospitalized for the first time and could not provide information on factors influencing relapse. Notwithstanding, they also showed concerns over their discharge, referring that they did not feel prepared to deal with cravings or to avoid relapse.

It is the first time I am hospitalized and I cannot imagine how it will be out there. Here I'm fine. I'm afraid to go back to using when I leave. The environment is complicated. (S22F)

I had never been hospitalized. I started using crack recently. I used and now I came here to get away from it. I will never use it again. (D27M)

Data on previous hospitalizations, last hospitalization, relapse, and number of attempts for the current hospitalization are shown in Table 4.

\section{Domain 3: Legal problems arising from the use of crack}

All men interviewed related the use of crack with trafficking, theft, robbery, and even imprisonment. Only one woman appeared in this section, also reporting having been arrested, but not mentioning theft or robbery. 
Table 4 - Hospitalization attempts and relapse

\begin{tabular}{|c|c|c|c|c|c|c|}
\hline $\begin{array}{l}\text { Name initial, } \\
\text { age and gender }\end{array}$ & $\begin{array}{l}\text { No. of previous } \\
\text { hospitalizations }\end{array}$ & $\begin{array}{l}\text { Place and duration } \\
\text { (days) of last } \\
\text { hospitalization }\end{array}$ & $\begin{array}{c}\begin{array}{c}\text { Final status } \\
\text { of last } \\
\text { hospitalization }\end{array} \\
\end{array}$ & $\begin{array}{l}\text { Time to relapse } \\
\text { after discharge } \\
\text { (days) }\end{array}$ & $\begin{array}{c}\text { No. attempts } \\
\text { to current } \\
\text { hospitalization? }\end{array}$ & $\begin{array}{c}\text { Hospitalization } \\
\text { status }\end{array}$ \\
\hline $\mathrm{S} 22 \mathrm{~F}$ & 0 & $\mathrm{NH}$ & $\mathrm{NH}$ & $\mathrm{NH}$ & 3 & $\mathrm{CO}$ \\
\hline M27F & 2 & TF, 20 & $A B$ & 1 & 1 & V \\
\hline R26F & 2 & $\mathrm{H}, 33$ & D & 3 & 1 & V \\
\hline E28F & 2 & $\mathrm{H}, 7$ & $A B$ & 1 & 3 & $\mathrm{~V}$ \\
\hline A29F & 3 & $\mathrm{H}, 21$ & D & 1 & 4 & $\mathrm{~V}$ \\
\hline P20M & 2 & $\mathrm{TF}, 10$ & $A B$ & 1 & 4 & $\mathrm{v}$ \\
\hline T22M & 6 & $\mathrm{H}, 42$ & D & 90 & 3 & $\mathrm{CO}$ \\
\hline J22M & 15 & $\mathrm{TF}, 23$ & $\mathrm{E}$ & 15 & 1 & $\mathrm{CO}$ \\
\hline N25M & 4 & $\mathrm{H}, 10$ & $A B$ & 1 & 5 & $\mathrm{CO}$ \\
\hline L25M & 6 & $\mathrm{H}, 21$ & $A B$ & 15 & 4 & V \\
\hline B27M & 2 & PC, 270 & $\mathrm{D}$ & 210 & 4 & $\mathrm{v}$ \\
\hline D27M & 0 & $\mathrm{NH}$ & $\mathrm{NH}$ & $\mathrm{NH}$ & 5 & $\mathrm{~V}$ \\
\hline I29M & 2 & $\mathrm{H}, 21$ & D & 2 & 3 & $\mathrm{~V}$ \\
\hline F30M & 13 & $\mathrm{H}, 35$ & $\mathrm{D}$ & 210 & 5 & $\mathrm{CO}$ \\
\hline
\end{tabular}

$\overline{\mathrm{AB}}=$ abandonment; $\mathrm{CO}=$ court order; $\mathrm{D}=$ discharge; $\mathrm{E}=$ exclusion; $\mathrm{H}=$ hospital; $\mathrm{NH}=$ never hospitalized; $\mathrm{PC}=$ private clinic; $\mathrm{TF}=$ therapeutic farm; $\mathrm{V}=$ voluntary.

When I was dating a drug dealer, the police appeared and arrested him. And I was handcuffed and arrested because the wife of drug dealer goes along. I was a rich girl who fell in love and settled in the slum. (R26F)

To buy crack I stole and robbed... I just was not arrested... yet. (P20M)

To get crack I stole and robbed. Of course this life of crime led me to jail. But the craving pushes us to do that. (T22M)

I am a normal guy... I even started college... but who has never committed a little crime... never stole anything from anyone... just picked up things at home to sell and buy crack. (F30M)

\section{Domain 4: Prostitution and HIV infection}

In this sample, all women reported to have engaged in prostitution because of crack. Conversely, none of the men reported involvement with sex in exchange for money or crack.

Who has never been hired out for sex for the drug? Addicts are like this... nothing else matters... crack erases the brain. Crack is all we think about, and the rest is the rest! (S22F)

Prostitution was complicated, but I was discrete and did it with my bosses at work. I didn't want the money. I wanted crack. (M27F)

I was hired out for sex just to get the drug. Crack craving is so strong that we exchange [sex for drug]. (R26F)

Two women reported having been infected with HIV. None of the men interviewed mentioned any sexually transmitted disease.
One night I was desperate for crack, and when I realized I had already become a prostitute. That's how it was from then on. Today I am HIV positive. (S22F)

I had sex for 30 or 40 reais and bought the stones. And now I am HIV positive. (R26F)

\section{Domain 5: Search for spiritual help}

With the exception of one subject, all interviewees believed that faith, religion, and spirituality could help crack users to remain abstinent after discharge from hospital.

My parents are Protestants but I do not believe it. If I ever quit crack it will be by myself. (S22F)

I don't go to church, but I pray every day to get away from this life. This is my way of believing. (A29F)

I always look up to God and Jesus. When I left the hospital I went to church twice. The following week I didn't go and relapsed. (I29M)

I... like to make it clear that spirituality is important to me; it's what kept me firm, but I didn't remain clean for long, see? (F30M)

\section{Discussion}

Our findings indicate that the traditional treatment seeking route starts at primary health care units, with treatment attempts ranging from one to five times in our sample until hospitalization was achieved. Treatment seeking trajectories among the crack users interviewed showed a relevant social characteristic of access to public health in Brazil, namely, that most users were only hospitalized once the family resorted to prosecutors to obtain a court order that would ensure their right to have 
a family member treated. This evidence suggests that the Brazilian public health care system still lacks appropriate approaches and programs to properly address the reality of the clientele seeking services.

Respondents described that the use of licit drugs by their relatives, such as tobacco and alcohol, increased their own use, although families were not held responsible for their own crack addiction. However, they described vulnerability resulting from indirect contact with other drugs and with drug paraphernalia used by relatives as factors responsible for experimentation, initiation, and dependence. ${ }^{15-18}$ This finding underscores the need to treat crack users taking into consideration a family perspective, which is often the perfect and favorable scenario for drug use, as already shown in literature and in our own data. ${ }^{19}$ Family structure among crack addicts is often dysfunctional, and if not dealt with adequately, may contribute to maintain drug use. In this sense, the public health care system should offer treatment programs that involve family members, with approaches aimed at helping identify factors that may encourage relapse and others that may strengthen family resilience. ${ }^{20}$

Although crack users define marijuana as a harmless and less impactful drug, they also mention that it served as a gateway to other illicit drugs. Previous studies ${ }^{17,21}$ have reported similar results, with marijuana being the first drug used in this transition. Therefore, we believe that treatment programs offered to drug users in general should design more effective strategies for marijuana users, in order to prevent further experimentation of other drugs, especially crack. Also, based on these findings, which are similar to results of previous studies, ${ }^{22,23}$ it seems that preventing the use of marijuana, which usually occurs in adolescence, may prevent the future use of other drugs. If treatment programs could offer a set of coping strategies and skills aimed at dealing with the supply and experimentation of drugs, the trajectory of teenagers who are offered marijuana in their transition from licit to illicit drugs might be potentially different. ${ }^{24-27}$

Our data demonstrate that crack dependence tends to settle quickly, commonly requiring more urgent treatment when compared with users of other drugs. ${ }^{6}$ However, current difficulties in access to treatment curtail this search, as reported in our interviews. Rather, crack users seeking treatment at the public health care system face so many difficulties that they end up having to try more than once, as noted in our findings and also in previous studies. ${ }^{4,18,28,29}$

Little is known about relapse rates among crack users after hospital discharge. ${ }^{26}$ According to our respondents, relapse is inevitable, and usually occurs shortly after discharge or abandonment of treatment. We therefore believe that treatment programs aimed at crack users should employ techniques and approaches dealing with coping strategies, so as to prevent relapse via skills training and craving management.

One respondent stated that depression and anxiety determined the end of his abstinence, so that when he started craving, he did not know what to do to avoid relapse. This statement emphasizes that psychiatric comorbidities should be diagnosed and treated as soon as possible, once they play an important role and can directly influence relapse after discharge - described in this sample as a sequence of signs. ${ }^{30,31}$

Only one respondent reported not to believe that spirituality could aid in maintaining abstinence from crack. Other subjects reported faith in God, but the relevance of spirituality as a protective factor against crack was not investigated. Our findings are in agreement with the study of Sanchez et al., which also found high rates of spirituality among drug users. ${ }^{32}$

The literature frequently describes samples of male crack users, while our study included reports of trajectories of both women and men. This decision was an attempt to improve our understanding of the complex profile of crack users, typically described as young, adult men, aged between 20 and 30 years. ${ }^{17,21}$

Our sample demonstrated behavior patterns regarding the use of crack which were peculiar to each gender. Men got involved with crime in an attempt to obtain the drug at any price - either stealing or trafficking - while women engaged in prostitution. Women reported not having other options to get the drug, deciding to expose themselves to the risk of acquiring sexuallytransmitted diseases such as HIV, in addition to violence and even unexpected pregnancies, also exposing their children to the drug. We speculate that these findings collected locally in fact reflect a national reality: Brazil lacks enough treatment units for crack users, especially female users, who are more vulnerable and more susceptible to its consequences. This scenario also points to an urgent need to expand studies involving women, which are still rare in the Brazilian literature. ${ }^{33-37}$

Another aspect was repeatedly shown in our sample: there are no treatment programs structured to meet the demands of female crack users. Our respondents were admitted to general psychiatric units, offering treatment to various disorders. We believe that treatment for female crack users, with specific programs and techniques, managed by specialists in drug dependence, would yield much more effective results in such an important public health issue.

This qualitative study has inherent limitations because it was designed based on intentional sampling criteria, i.e., the results obtained for the selected sample cannot 
be extrapolated to the general population of crack users. However, our study raised important questions about treatment - questions that do not yet have definitive answers yet, but demand accurate reflection of society as a whole, and particularly of professionals working with addiction.

The use of crack is becoming increasingly popular as a result of innovative trafficking and market strategies, such as online sales and home delivery, and needs to be controlled. 17,21,38 Moreover, the close relationship between crack use and legal complications arising from its use, such as violent behavior and crime, and the psychological and social damage associated with the drug, are all aspects that should be taken into consideration when dealing with this major health concern. ${ }^{16,39,40}$

\section{Conclusions}

Our study underscored the importance of understanding drug use and treatment seeking trajectories among crack users and also of developing real treatment actions aimed at this specific population. Our sample of users believed that their gateway for the use of illicit drugs was the use of licit drugs by family members, and that relapse after discharge is strictly related to a social environment conducive to drug use, to belief or disbelief in spiritual aid, and to legal problems arising from the use of crack.

Both male and female interviewees reported the use of different psychoactive substances; however, according to their reports, crack was the drug that imposed major changes to their lives. Crack dependence involved not only the compulsive use of the drug, but also a large range of dysfunctional behaviors that increasingly interfered with their relationships with family, school, work, and friendships, regardless of gender.

Finally, our findings point to the relevance of studying the use of crack at larger scales, raising awareness for new treatments and for (the so often mentioned but so rarely practiced) preventive strategies in the public health care system.

\section{References}

1. Ferri CP, Laranjeira RR, da Silveira DA, Dunn J, Formigoni ML. Aumento da procura de tratamento por usuários de crack em dois ambulatórios na cidade de São Paulo: nos anos de 1990 a 1993. Rev Assoc Med Bras. 1997;43:25-8.

2. Siegal HA, Falck RS, Wang J, Carlson RG. Predictors of drug abuse treatment entry among crack-cocaine smokers. Drug Alcohol Depend. 2002;68:159-66.

3. Siegal HA, Li L, Rapp RC. Abstinence trajectories among treated crack cocaine users. Addict Behav. 2002;27:437-49.
4. Falk R, Wang J, Carlson R. Crack cocaine trajectories among users in a midwestern American city. Addiction. 2007; 102:1421-31.

5. Hser YI, Longshore D, Anglin MD. The life course perspective on drug use: a conceptual framework for understanding drug use trajectories. Eval Rev. 2007;31:515-47.

6. Nappo SA, Sanchez Z, De Oliveira LG. Crack, AIDS, and women in São Paulo, Brazil. Subst Use Misuse. 2011;46:476-85.

7. Patton M. Qualitative evaluation and research methods. London: Sage; 1990.

8. Diaz A, Barruti M, Doncel C. The line of the success? A study on the nature and extent of cocaine use in Barcelona. Barcelona: Laboratori de Sociologia/ICESB; 1992.

9. Minayo M. O desafio do conhecimento - pesquisa qualitativa em saúde. São Paulo/Rio de Janeiro: Hucitec/Abrasco; 1993.

10. Melotto P. Trajetórias e usos de crack: estudo antropológico sobre trajetórias de usuários de crack no contexto de bairros populares de São Leopoldo, RS [dissertação]. Porto Alegre: Universidade Federal do Rio Grande do Sul; 2009.

11. Fontanella BJ, Luchesi BM, Saidel MG, Ricas J, Turato ER, Melo DG. Amostragem em pesquisas qualitativas: proposta de procedimentos para constatar saturação teórica. Cad Saude Publica. 2011;27:389-94.

12. Biernacki $P$, Waldorf $D$. Snowball sampling: problems and techniques of chain referral sampling. Sociol Methods Res. 1981;10:141-63.

13. Iervolino SA, Pelicioni MC. The use of focal groups as qualitative method in health promotion. Rev Esc Enferm USP. 2001;35:115-21.

14. Bardin L. Análise de conteúdo. Lisboa: Edições 70; 2009.

15. Sanchez ZM, de Oliveira LG, Ribeiro LA, Nappo SA. The role of information as a preventive drug measure among youth at risk. Cienc Saude Coletiva. 2011;16 Suppl 1:1257-66.

16. Oliveira L, Nappo S. Crack na cidade de São Paulo: acessibilidade, estratégias de mercado e formas de uso. Rev Psiquiatr Clin. 2008;35:212-8.

17. Moreira F, Silveira D, Andreoli S. Situações relacionadas ao uso indevido de drogas nas escolas públicas da cidade de São Paulo. Rev Saude Publica. 2006;40:810-7.

18. Ferreira Filho O, Turchi M, Laranjeira R, Castelo A. Perfil sociodemográfico e de padrões de uso entre dependentes de cocaína hospitalizados. Rev Saude Publica. 2003;37:751-9.

19. Pratta EM, Santos MA. Uso de drogas na família e avaliação do relacionamento com os pais segundo adolescentes do ensino médio. Psico. 2009;40:32-41.

20. Hidalgo Carmona CG, Santis Barros R, Rodríguez Tobar J, Hayden Canobra V, Anselmo Montequín E. Family functioning of out-of-treatment cocaine base paste and cocaine hydrochloride users. Addict Behav. 2008;33:866-79.

21. Oliveira L, Nappo S. Caracterização da cultura de crack na cidade de São Paulo: padrão de uso controlado. Rev Saude Publica. 2008;42:664-7.

22. Degenhardt L, Coffey C, Carlin JB, Swift W, Moore E, Patton GC. Outcomes of occasional cannabis use in adolescence: 10-year follow-up study in Victoria, Australia. Br J Psychiatry. 2010;196:290-5.

23. Fergusson DM, Boden JM, Horwood LJ. Cannabis use and other illicit drug use: testing the cannabis gateway hypothesis. Addiction. 2006;101:556-69.

24. Chaney EF, O'Leary MR, Marlatt GA. Skill training with alcoholics. J Consult Clin Psychol. 1978;46:1092-104.

25. Fox HC, Axelrod SR, Paliwal P, Sleeper J, Sinha R. Difficulties in emotion regulation and impulse control during cocaine abstinence. Drug Alcohol Depend. 2007;89:298-301. 
26. Araujo RB, Pansard M, Boeira B, Rocha N. As estratégias de coping para o manejo da fissura de dependentes de crack. Rev HCPA. 2010;30:36-42.

27. Ribeiro LA, Sanchez ZM, Nappo SA. Surviving crack: a qualitative study of the strategies and tactics developed by Brazilian users to deal with the risks associated with the drug. BMC Public Health. 2010;10:671-81.

28. Moraes M. O modelo de atenção integral à saúde para tratamento de problemas decorrentes do uso de álcool e outras drogas: percepções de usuários, acompanhantes e profissionais. Cienc Saude Coletiva. 2008;13:121-33.

29. Rameh de Albuquerque R. Casas do meio do caminho: um relato da experiência de Recife na busca da atenção integral à saúde dos usuários de álcool, fumo e outras drogas [dissertação]. Rio de Janeiro: Fiocruz; 2008.

30. Guimarães C, Santos D, Freitas R, Araujo R. Perfil do usuário de crack e fatores relacionados à criminalidade em unidade de internação para desintoxicação no Hospital Psiquiátrico São Pedro de Porto Alegre (RS). Rev Psiquiatr Rio Gd Sul. 2008;30:1-8.

31. Silva C, Kolling N, Carvalho J, Cunha S, Kristensen C. Comorbidade psiquiátrica em dependentes de cocaína/crack e alcoolistas: um estudo exploratório. Aletheia. 2009;30:101-12.

32. Sanchez ZM, Oliveira LG, Nappo AS. Fatores protetores de adolescentes contra o uso de drogas com ênfase na religiosidade. Cienc Saude Coletiva. 2004;9:43-55.

33. Pechansky F, Kessler F, Von Diemen L, Bumaquin D, Surrat $H$, Inciardi J. Brazilian female crack users show elevated serum aluminium levels. Rev Bras Psiquiatr. 2007;29:39-42.

34. Nunes CL, Andrade T, Galvão-Castro B, Bastos FI, Reingold A. Assessing risk behaviors and prevalence of sexually transmitted and blood-borne infections among female crack cocaine users inSalvador--Bahia, Brazil. Braz J Infect Dis. 2007;11:561-6.
35. Malta M, Monteiro S, Lima R, Bauken S, Mrco A, Zuim G, et al. HIV/AIDS risk among female sex workers who use crack in souther Brazil. Rev Saude Publica. 2008;42:830-7.

36. Carvalho HB, Seibel SD. Crack cocaine use and its relationship with violence and HIV. Clinics (Sao Paulo). 2009;64:857-66.

37. Von Diemen L, De Boni R, Kessler F, Benzano D, Pechansky F. Risk behaviors for HCV- and HIV-seroprevalence among female crack users in Porto Alegre, Brazil. Arch Womens Ment Health. 2010;13:185-91.

38. Ribeiro M, Dunn J, Sesso R, Dias A, Laranjeira R. Causes of death among crack cocaine users. Rev Bras Psiquiatr. 2006;28:196-202.

39. Bungay V. Women's health and use of crack cocaine in context: structural and 'everyday' violence. Int J Drug Policy. 2010;21:321-4.

40. Reuben J, Serio-Chapman C, Welsh C, Matens R, Sherman S. Correlates of current transactional sex among a sample of female exotic dancers in Baltimore, MD. J Urban Health. 2011;88:342-51.

\section{Correspondence}

Rosemeri Siqueira Pedroso

Center for Drug and Alcohol Research

Hospital de Clínicas de Porto Alegre

Rua Prof. Álvaro Alvim, 400

90420-020 - Porto Alegre, RS - Brazil

Tel./Fax: +55-51-3359-6472

E-mail: rosemeripedroso@yahoo.com.br 